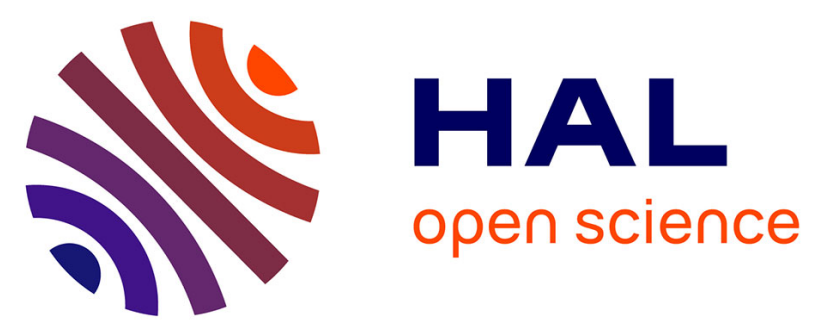

\title{
A concept-oriented analysis of future-time reference in native and near-native Hexagonal French
}

Amanda Edmonds, Aarnes Gudmestad, Bryan Donaldson

\section{To cite this version:}

Amanda Edmonds, Aarnes Gudmestad, Bryan Donaldson. A concept-oriented analysis of future-time reference in native and near-native Hexagonal French. Journal of French Language Studies, 2017, 27 (3), pp.381-404. 10.1017/S0959269516000259 . hal-03063017

\section{HAL Id: hal-03063017 https://hal.science/hal-03063017}

Submitted on 9 Feb 2021

HAL is a multi-disciplinary open access archive for the deposit and dissemination of scientific research documents, whether they are published or not. The documents may come from teaching and research institutions in France or abroad, or from public or private research centers.
L'archive ouverte pluridisciplinaire HAL, est destinée au dépôt et à la diffusion de documents scientifiques de niveau recherche, publiés ou non, émanant des établissements d'enseignement et de recherche français ou étrangers, des laboratoires publics ou privés.

\section{(ㅇ)(1) $\$$}

Distributed under a Creative Commons Attribution - NonCommercial - NoDerivatives| 4.0 


\title{
PRE-PRINT VERSION
}

Edmonds, A., Gudmestad, A., \& Donaldson, B. (2017). A concept-oriented analysis of future-time reference in native and near-native Hexagonal French. Journal of French Language Studies, 27(3), 381-404.

A Concept-Oriented Analysis of Future-Time Reference in Native and Near-Native Hexagonal French

\begin{abstract}
This study examined how native and near-native speakers of Hexagonal French make reference to future events in a corpus of informal conversations. A concept-oriented analysis reveals that no fewer than 13 different finite verb forms appeared in future-time contexts. A qualitative analysis of the use of the present in future-time contexts in the two portions of the corpus points to similarities in the native-speaker and near-native-speaker use. This analysis contributes to the understanding of future-time expression in Hexagonal French and to discussions concerning near-nativeness in second language acquisition.
\end{abstract}

Keywords: future-time reference, temporality, Hexagonal French, near-native speakers, concept-oriented approaches

\section{Introduction}

Although previous studies recognize that the expression of futurity in French can be accomplished in a variety of ways, most have consistently simplified the future-time reference sector to the two or three most frequent verb forms used to make reference to future time. In contrast, data from the present study will show that future-time expression in French in fact draws on a rich inventory of finite verb forms. Our main goal is to provide a more complete picture of verb forms used in future-time expression by a group 
of native speakers (NSs) and near-native speakers $(\mathrm{NNSs})^{1}$ of Hexagonal French engaging in informal conversation. To capture the full repertoire of verbal means appearing in future-time contexts, and to avoid a priori assumptions based on morphological form, we adopt a concept-oriented approach to the analysis of future-time expression. We agree with Kanwit (2014: 16), who writes, '[o]verall, concept-oriented approaches are highly justified, given that many linguistic functions are filled by multiple forms, such that limiting the list of permissible forms a priori results in an inadequate analysis that is certain to exclude the full account of forms that may be used in a given context.'

Our corpus allows us to contribute to research on both native and non-native French. The analysis of the NS portion contributes to discussions of the expression of future-time in Hexagonal French, which has received much less attention than Canadian varieties with respect to future-time expression. Moreover, the NS data provide an ecologically valid baseline against which to compare the expression of future time by our NNSs. As concerns non-native French, the current corpus allows us to examine to what extent forms used to make future-time reference by second-language (L2) speakers with proficiency at the highest levels of L2 attainment resemble NSs' repertoires. In what follows, we begin by briefly discussing our analytical framework before reviewing previous studies on future-time reference in NS and L2 French. We then present what is, to our knowledge, the first concept-oriented study of future-time expression in NS and NNS Hexagonal French. Finally, we discuss our results and the importance of our findings for research on NS and L2 French.

\footnotetext{
${ }^{1}$ In this paper, the abbreviation NNS will refer exclusively to near-native speaker (and not to non-native speakers more generally, which will be referred to with the term second-language [L2] speaker).
} 


\section{Background}

In this study, we adopt a functional (and, in particular, concept-oriented) approach in order to examine future-time expression in French. Functional approaches to linguistics focus on the making of meaning within communication, and include variationist approaches (Aaron, 2010: 30), form-function approaches, and conceptoriented approaches. Variationist sociolinguistic studies, for example, examine a variety of linguistic and extralinguistic factors that influence the choice of two or more means of expressing a similar notion. With respect to future-time expression in French, variationist studies have shown, among other things, that the presence of sentential negation or a temporal adverbial generally favors the use of the inflectional future over the periphrastic future (e.g., Poplack and Turpin, 1999). Form-function approaches, on the other hand, track a single form throughout the language system in an attempt to understand the range of linguistic functions it fulfills (Ellis, 2008). For future-time expression, a form-function analysis of the IF would reveal not only this form's use in the expression of futurity, but also its use as a pseudo-imperative (tu poseras ce livre tout de suite!) or an epistemic (il n'est pas ici il sera malade [example from Jeanjean, 1988: 253]).

A concept-oriented (or function-form) approach aims to capture the full range of expression used for a given concept. In such studies, the researcher first identifies a concept (e.g., future-time reference) and then inventories and analyzes all linguistic forms used to express this concept (Bardovi-Harlig, 2007; von Stutterheim and Klein, 1987). We adopt this approach for the study of the future-time reference sector, arguing that it is particularly well suited to the study of different temporal domains. As L. de Saussure 
notes, 'tenses do not or not only refer to the time(s) they should refer to according to their intuitive semantics: some present tense utterances tell about a past or a future; some utterances with a past tense tell about a present or a future; some future tense utterances are about the present or the past' (2013: 47).

\section{Future-Time Reference in French}

Most previous studies into future-time reference in French have presented a restricted view, concentrating on two or three verb forms: the inflectional future (IF), the periphrastic future $(\mathrm{PF})$, and to a lesser extent the futurate present (also referred to as the present-for-future). Examples of each, drawn from the present corpus, appear in (1).

(1) a. IF: comme ça on aura un deuxième avis (NS7, 310)

b. PF: je vais avoir certainement des détails demain (NS7, 322)

c. futurate present demain je n'ai que deux heures (NS5, 258) Poplack and Dion's comprehensive 2009 study shows that much previous research and grammatical commentary have held that these three forms largely occur in distinct futuretime contexts. It has been contended that the IF shows a break from present time, making it particularly congruent with the expression of hypothetical (i.e., negative), distal, and uncertain events. In contrast, because the PF is anchored in the present, it is argued to be compatible with events set to occur in the proximal future, or with events that are certain to occur. The use of the futurate present is most often linked to the presence of a temporal adverbial (e.g., Blondeau, 2006: 74; Le Goffic and Lab, 2001: 78; Moses, 2002: 27). However, Poplack and Dion convincingly debunk such a clear-cut functional division among these forms, showing (a) striking inconsistencies across five centuries of grammatical tradition and (b) highlighting the necessity of empirical research in the study 
of future expression. For this reason, in the face of a large literature, we privilege empirical accounts of future-time expression in spoken French in our review of previous studies.

\section{Future-Time Reference in NS French}

There exist numerous studies into the expression of future-time reference in Laurentian (Blondeau, 2006; Deshaies and Laforge, 1981; Emirkanian and Sankoff, 1985; Grimm, 2010, 2015; Grimm and Nadasdi, 2011; Poplack and Dion, 2009; Poplack and Turpin, 1999) and Acadian (Comeau, 2011; King and Nadasdi, 2003) varieties of French, almost all of which have concentrated exclusively on the two verb forms morphologically marked for future: PF and IF (cf. Poplack and Turpin, 1999). In comparison, studies of future expression in Hexagonal French are underrepresented. Existing studies have examined the distributions of the two or three main verb forms in corpora with adult speakers (Fleury and Branca-Rosoff, 2010; Hansen and Strudsholm, 2006; Jeanjean, 1988; Roberts, 2012; Wales, 1983) or child participants (Söll, 1983). For the present study, two particularly relevant findings with respect to IF and PF emerge from this body of research. First, previous authors have been interested in the overall frequency of verb forms used in the expression of future-time, although no consensus prevails: Whereas both Wales and Jeanjean report a predominance of IF, Fleury and Branca-Rosoff, Söll, and Roberts all find that the PF is the more frequent form. ${ }^{2}$ Second, all studies except Wales examine how speakers use future-situating time adverbials when talking about the future, and all note a tendency for the IF to occur in the company of such adverbials, and in particular of non-specific ones (e.g., une fois).

\footnotetext{
${ }^{2}$ Hansen and Strudsholm only report raw frequencies for all IF, PF, and present forms, regardless of whether they are found in future-time contexts.
} 
The present tense, although generally recognized as a player in future expression, is rarely given the same attention as the forms carrying future morphology. In fact, we know of no empirical study on its use for future expression in spoken Hexagonal French. When it is discussed, the consensus is that the present must be accompanied by a futuretime adverbial to be construed as making reference to the future. Moses' (2002: 27) definition is representative of this view: the futurate present is 'the use of present tense verb morphology accompanied by an obligatory future-marking time adverbial to express a chronologically future event.' Le Goffic and Lab (2001: 77) also recognize that the presence of an explicit date is necessary, 'sauf bien entendu si la date est implicite mais récupérable dans le contexte'.

Previous research into future-time expression in Hexagonal French thus leaves open numerous questions, of which three will receive particular attention in this article. First, no previous study has attempted to capture the full range of finite verb forms used in future-time contexts, concentrating instead on the IF and the PF. Second, disagreements persist as to the relative frequency of these two forms. Finally, although it is recognized that the present can be used in future-time contexts, in particular in the company of temporal adverbials, we know of no empirical investigation into its use.

\section{Future-Time Reference in L2 French}

Previous L2 research on future-time expression in spoken French has revealed several findings, two of which are relevant for the current study. First, previous studies have reported frequency of use for the PF, IF, and present. Both Howard (2012) and Moses (2002) report that advanced university learners continue to underutilize the PF (as compared to the IF), even after a year abroad in the case of Howard's learners. 
Adolescents in an immersion setting (Nadasdi, Mougeon, and Rehner, 2003) and Anglophones living in Montreal (Blondeau, Dion, and Ziliak Michel, 2014), on the other hand, come close to approximating the norm in Laurentian French (however, 14\% of forms used by the immersion students were non-native). Second, two studies (Moses and Blondeau et al.) look beyond the PF, IF, and futurate present. Blondeau et al. report that conditional forms occurred in some of the future-time contexts produced by their participants, whereas Moses finds future-time contexts expressed with the futur antérieur, the present subjunctive, and lexical futures in the speech of his NSs and L2 learners.

Although these findings aid in understanding how L2 speakers of French make reference to future time, several issues remain unresolved, two of which will be examined in the present study. First, the findings suggest that nativelike approximation of the future-time reference sector (with respect to frequency, forms, and linguistic factors) is difficult for even advanced learners; only Blondeau et al. (2014) find that their learners, living in a target language environment, succeed. In this study, however, the authors concentrate on the use of the IF, PF and present, leaving open the question as to whether the L2 speakers rely solely on the major players in future-time expression. Second, Moses (2002) represents the only attempt to provide a full picture of future-time expression. His study, however, looked at 24 learners in a university setting (at four proficiency levels), and included only between 73 and 187 tokens per group. Additional work that will extend Moses' findings to more advanced learners using a larger dataset is thus merited.

\section{Research Questions}

Previous research on NS French has generally been limited to the IF and the PF. Whereas L2 research has investigated a wider palette of forms, no study has examined the 
full range used by NNSs to express future-time. For the first research question guiding the present project, we asked what finite verb forms are used to express the function of future-time reference in informal conversation by NSs and NNSs of Hexagonal French, and whether the inventories and their distributions differ for the two groups. In responding to this question, it became clear that present forms were more strongly represented in our corpus than has been reported in previous research, both for NSs and for NNSs. For this reason, we investigated a second research question: How are present forms used to express the function of future-time in informal conversation, and do the NSs and NNSs differ in their use?

\section{The Current Study}

Our study is based on a corpus comprised of 10 dyadic conversations between a NNS of French and a NS friend, spouse, or close acquaintance of the NNS. ${ }^{3}$ This section provides details about the participants and the corpus, as well as information regarding data coding and analysis.

\section{Participants}

To constitute the corpus, NNSs of French whose L1 was English were contacted through advertisements, personal networking, and a local Anglophone club in the Southwest of France. An initial sample of approximately 20 candidates who had been living in France for at least four years and who had attained a self-described high level of

\footnotetext{
${ }^{3}$ Although an anonymous reviewer questions whether the NS data is valid, given that they were speaking with NNSs, research conducted by Donaldson (2016, in press) has shown with respect to other linguistic features that the NNSs in this corpus are performing at a level similar to the NSs. In addition, we point out that multilingualism is widespread in Europe (where these data were collected), and that interactions with NNSs is by no means exceptional. In that respect, we argue that the data presented here provide an ecologically valid representation of informal discussion in a European context.
} 
mastery in French was identified. The ten individuals from this initial pool with the highest proficiency levels, as measured by a replication of Birdsong's (1992) French grammaticality judgment task (see Donadlson, 2011, for further details) were retained and deemed to possess proficiency comparable to other near-native populations reported in the literature. All NNSs were university-educated and received their first instruction in French at age 10 or higher $(M=13 ; 0$ years); additional details appear in Table 1.

Table 1. Characteristics of the NNSs.

\begin{tabular}{|c|c|c|c|c|c|c|c|c|c|c|}
\hline \multirow[b]{2}{*}{ Characteristics } & \multicolumn{10}{|c|}{ NNSs } \\
\hline & 1 & 2 & 3 & 4 & 5 & 6 & 7 & 8 & 9 & 10 \\
\hline Sex & $\mathrm{F}$ & $\mathrm{F}$ & $\mathrm{F}$ & $\mathrm{F}$ & $\mathrm{F}$ & $\mathrm{F}$ & $\mathrm{F}$ & $\mathrm{M}$ & $\mathrm{F}$ & $\mathrm{M}$ \\
\hline Age & 52 & 40 & 27 & 39 & 45 & 70 & 34 & 26 & 57 & 52 \\
\hline Country of birth & US & UK & US & US & UK & UK & US & US & US & UK \\
\hline AOI & 21 & 11 & 13 & 13 & 11 & 10 & 10 & 16 & 14 & 11 \\
\hline $\mathrm{AOE}$ & 23 & 20 & 16 & 20 & 17 & 20 & 20 & 21 & 20 & 20 \\
\hline Education & BA & BA & BTS & MBA & MA & MA & JD & BA & BA & $\mathrm{PhD}$ \\
\hline LOR & $27 ; 3$ & $18 ; 7$ & $7 ; 2$ & $9 ; 0$ & $14 ; 3$ & $47 ; 3$ & $5 ; 9$ & $4 ; 3$ & $27 ; 10$ & $>25^{*}$ \\
\hline \multicolumn{11}{|c|}{ Note. $\mathrm{AOI}=$ age of first instruction in French; $\mathrm{AOE}=$ age of first significant exposure to } \\
\hline $\begin{array}{l}\text { French; LOR = le } \\
\text { provided) }\end{array}$ & igth of & resider & ce at ti & \multicolumn{6}{|c|}{ provided) } & OR not \\
\hline Each NNS partic & ant se & ected & a Frenc & h NS fr & iend, $\mathrm{sl}$ & pouse, & or clos & e acq & uaintance & e wit \\
\hline
\end{tabular}


Table 2. Characteristics of the NSS.

NSs

Characteristics

\begin{tabular}{llllll}
\hline & 2 & 3 & 4 & 5
\end{tabular}

6

$\begin{array}{llll}7 & 8 & 9 & 10\end{array}$

\begin{tabular}{lllllllllll}
\hline Sex & F & F & F & M & M & F & F & M & F & F
\end{tabular}

Age

$46 \quad 46 \quad 31$

$42 \quad 55$

62

$31 \quad 34 \quad 65$

54

Education

BAC BA MA PhD

BA MA

BA BA

BA PhD

\section{Corpus Characteristics}

The present corpus differs from other corpora used in the previous literature on future-time expression. Rather than conducting a sociolinguistic interview, which generally involves an interviewer unknown to the participant, the researcher played no active role. Instead, each NNS and his or her self-selected NS counterpart were recorded conversing in a casual, informal setting for between 45 and 58 minutes. The resulting 8.3 hour corpus is comprised of 77,300 words (excluding non-lexical backchannels, hesitations, etc.) and is quantitatively balanced between NS and NNS contributions (see Donaldson 2011). Importantly, no researcher was present during the conversation, and participants were free to discuss whatever they wished. The decision to ask each NNS to select his or her NS interlocutor was made to facilitate the use of an informal register on the part of both speakers, resulting in a speech sample that reflects freely occurring conversation. These corpus characteristics suggest strongly that the data are representative of the speakers' everyday informal speech.

\section{Data Coding}


The 10 conversations were transcribed by the third author and each was subsequently checked for accuracy by a NS of French with advanced graduate training in linguistics. The data coding procedure involved three phases. To begin, all three authors independently coded the same transcript (conversation NNS1/NS1). In the second phase, the remaining nine transcripts were each coded by one author. Finally, those nine transcripts were recoded by a second author. Thus, each part of the corpus was coded (minimally) by two different researchers. At each phase, disagreements were discussed and resolved among the three authors

We identified as a future-time context any finite predicate whose realization was clearly set to occur after the moment of speaking (see Blondeau et al., 2014: 678, for a similar definition). To identify such contexts, we relied on contextual cues, such as temporal adverbials, discourse context, and shared knowledge between the interlocutors. To illustrate our analysis, we will discuss the extract presented in (2). In this extract the participants are discussing a new colleague who will arrive the Thursday after the conversation. We contend that the ten verbs bolded all occur in future-time contexts. In the first example, the future-time adverbial jeudi prochain corroborates the future morphology on viendra, and establishes "next Thursday" as a discourse topic and a future time frame, both of which will be maintained jointly by the two speakers throughout this extract. Despite the absence of future morphology, où on montre les copies can only be interpreted as occurring next Thursday, as reaffirmed by the temporal adverbial le six, which is co-referential with jeudi prochain. Similarly, je serai(s) à Bordeaux refers to NNS10's plans for next Thursday. Future morphology appears in the fourth context (on verra); this predicate will be realized after the moment of speaking. The next three 
examples - t'es pas là, ça se termine, and y a un déjeuner - all show present-tense morphology, yet all three clearly refer to next Thursday. The continued reference to next Thursday guides the interpretation of the final three bolded examples: the PF in je vais surement pas rester, and the present indicative in c'est aux Chartrons and je suis à la maison. Note however that despite the overarching reference to next Thursday, not all finite verbs in this discourse topic make reference to future time: $j$ 'ai accepté, for example, can only be interpreted as past-time reference.

(2) $\quad \operatorname{NS} 10(419,436):{ }^{4}$ donc elle viendra très probablement jeudi prochain jour le où on montre les copies le jour des résultats le six

NNS10 (417): oui alors moi je serai(s) à Bordeaux jusqu'à midi et demie j'ai accepté de remplacer quelqu'un au pied levé pour ah une traduction simultanée NS10 (420, 439): bah écoute on verra hein si t'es pas là t'es pas là NNS10 (482, 461, 484, 483): mais donc si je pars à ... Apparemment ça se termine à midi et demie y a un déjeuner mais je vais surement pas rester pour le déjeuner c'est aux Chartrons je crois donc je suis à la maison 'fin ici

NS10: oui bon enfin

NNS10: à trois heures

Given our concept-oriented analysis, a number of finite verbs with future-tense morphology were excluded. First, we excluded contexts involving what Poplack and Turpin (1999) referred to as false futures (e.g., use of PF or IF to make hypothetical statements, refer to spatial movement, or refer to habitual actions). Second, our definition

\footnotetext{
${ }^{4}$ In each example, a number given between parentheses corresponds to the reference assigned to each future-time token in our corpus; the finite verb occurring in a future-time context is bolded.
} 
of future-time context as occurring after the time of speech excludes references to the future in a past-time discourse setting, such as the series of IF forms seen in (3).

(3) NS5 : mais mais ce qui alors je disais à Guy bon pour pour abattre cet arbre et pour le débiter tu n'auras qu'à venir je viendrai(s) je viendrai(s) te chercher et puis y aura qu'à prendre la remorque

\section{Data Analysis}

We began by identifying all verb forms used in the expression of futurity by the NSs and NNSs, and then compared the two inventories with each other and with previous research (research question 1). For the second research question, we conducted a qualitative analysis into how the NSs and NNSs used the present in order to make reference to future time, focusing on the presence of temporal adverbials and the use of subjunctive forms.

\section{Results}

\section{Inventories of Verb Forms used in Future-Time Expression}

A total of 502 future-time contexts were identified in the NNS portion of the corpus, and 445 were found in the NS contributions. An inventory of thirteen different verb forms was identified, an example of each appears in (4). ${ }^{5}$

(4) PF:

tu vas pouvoir faire une expo bientôt (NS1,28)

Present indicative : je te fais un café (NS4, 201)

Present subjunctive: faut qu'on vienne te voir $(\mathrm{NS} 1,60)$

Present ambiguous: NNS1 : non attends je vais t'montrer

\footnotetext{
${ }^{5}$ Due to space constraints, it is not possible to provide additional context for each example, which is necessary for some examples in order to understand the reference to the future.
} 
NS1 (42) : il faut que je voie [vwa] ça

IF: t'as l'impression que tu pourras pas survivre ici (NS1, 25)

IF-conditional: $\quad$ je pense que j'aurai(s) besoin d'aide (NS4, 158)

Conditional : $\quad$ NS8 : et avec ... tu vas voyager en tongs

NNS8 : ça fait mal aussi le tong

NS8 (345) : mais à mon avis ça te ferait moins mal avec

tes: Birkenstock

PF subjunctive: $\quad$ il faudrait que samedi matin j'aille faire du stretching (NS3,

Futur antérieur: $\quad$ il aura oublié l'anglais (NS7, 298)

Futur antérieur (cond): demain j'aurai(s) terminé de faire le jardin (NS5, 206)

Lexical future : $\quad$ demain après-midi quand tu reviens on peut aller chez le pépiniériste (NS5, 213)

Lexical future (IF-cond): je n' sais plus je pourrai(s) lui demander (NS6, 279)

Lexical future conditional: et puis on voudrait s'arrêter deux jours à Londres au retour (NS1, 20)

This inventory reveals a rich picture of verbal resources available in the expression of future time, a picture that goes far beyond the IF, PF, and present. Several of the categories necessitate additional comments, as they have not generally been found in previous studies: the distinction among three types of present forms, the IF-conditional forms (IF-conditional, futur antérieur [cond], lexical future [IF-cond]), and the lexical future forms. 
Beginning with the present forms, previous studies appear to have restricted their analyses to tokens of the present indicative. Explicitly stated by certain authors (e.g., Nadasdi et al., 2003; Poplack and Dion, 2009), others imply this restriction, as the only examples given of the futurate present are presumably indicative ones (e.g., Moses, 2002; Roberts, 2012). We say "presumably" indicative, as many subjunctive forms are phonetically non-distinct from indicative ones in oral French, making it impossible to know whether the form in question is indicative or subjunctive, as in (5a) and (5b). In example (5a), the NNS1 is talking about a costume she has made for an upcoming show and wants to show NS1. In (5b), NS7 has just said that she should be able to recuperate an object left with NNS7 and give it to other friends that she intends to see Thursday evening.
a. NNS1 : non attends je vais t'montrer
NS1 (42): il faut que je voie ça
b. NS7 (340) : parce qu'on les voit jeudi soir

Despite the fact that the phonetic realization of voie and voit are identical and that both predicates expressed with voir will occur in the future, we presume that previous studies would have excluded (5a), on the grounds that it was transcribed as a subjunctive form, but included the presumably indicative $(5 b)$ in their analysis. In our own future-time contexts, we found unambiguously present indicative forms, unambiguously present subjunctive forms, and present forms that are phonetically non-distinct in the subjunctive and indicative moods. Given that mood distinction has been shown to be variable in French (Gudmestad and Edmonds, 2015; Poplack, Lealess, and Dion, 2013), we prefer to 
make no judgment as to the mood marking of the ambiguous forms. For this reason, we coded them separately as present ambiguous.

We faced a similar challenge in our coding of certain first-person singular forms. For many speakers of Hexagonal French, the only difference between the conditional and IF for the first-person singular is an orthographic one: j'aurai (IF) versus $j$ 'aurais (conditional). The pronunciation distinction made between these two forms by some speakers opposes the mid-close vowel $[\mathrm{e}]$ of the IF to the mid-open vowel $[\varepsilon]$ of the conditional; for most speakers, however, both j'aurai and j'aurais are now pronounced with the mid-close variant, especially in casual, unmonitored speech (Gueunier, Genouvrier, and Khomsi, 1978: 70). It is thus impossible for such tokens to determine whether the speaker used the IF or the conditional. For this reason, we followed Fleury and Branca-Rosoff (2010) in creating a separate category for these forms: IF-cond included only instances of the first-person singular in the IF or conditional (a similar category exists for first-person examples of the futur antérieur and lexical future conditionals: futur antérieur [cond] and lexical future [IF-cond]). In our data, we transcribed these forms in the following manner: je serai(s) à Bordeaux (NNS10, 417). Given that most previous research has concentrated on morphological form, it seems likely that a priori (presumably prescriptively informed) decisions about what is an IF form and what is a conditional form were made during the transcription process (much as would be the case for the subjunctive vs. indicative examples given in [5]), and that subsequently extracted IF forms thus reflect prescriptive distinctions.

The final group of forms that we would like to highlight are the three lexical futures (e.g., I want to go to the movies). As a group, lexical futures are periphrastic 
constructions with agent-oriented modalities. They involve the use of a first verb (generally denoting desire, obligation, ability or attempt) making reference to a present state about a future action (see Bybee, Perkins, and Pagliuca, 1994). According to Bardovi-Harlig (2005: 1), lexical futures are 'often overtly modal.' In our project, three types of lexical futures were identified: instances where the first verb is conjugated in the present (6a), examples where the first verb is unambiguously in the conditional (6b), and instances of the first-person singular that are phonetically non-distinct between the conditional and the IF (6c).

(6) a. lexical future: les chauffeurs routiers doivent travailler (NS5, 212)

b. lexical future conditional: est-ce que tu pourrais passer à la

bibliothèque (NS10, 406)

c. lexical future (IF-cond): lundi comme c'est un jour férié j'aimerai(s) pouvoir finir cet arbre dans le jardin (NS5, 218)

In all three examples, the action - travailler, passer, and pouvoir - will happen at a future time, whereas the finite verb expresses a present state about the future action. Lexical futures have not, to the best of our knowledge, been addressed in research on NS French (but Moses, 2002, includes them among "other forms" in his investigation of the development of future-time reference in L2 French). Moreover, although they have been investigated in L2 English (Bardovi-Harlig, 2005) and in L2 Spanish (Kanwit, 2014), we differ from this previous research in that we identify three lexical future forms (see examples in [6]). In our dataset, lexical futures involve the following verbs: aimer, avoir $\grave{a}$, avoir envie, compter, devoir, pouvoir, and vouloir. 
NS inventory and distribution. NSs produced a total of 13 different verb forms and 111 different lexical verbs in 445 future-time contexts. The 13 verb forms were used by NSs with varying frequencies, as seen in Tables $3 \mathrm{a}$ and $3 \mathrm{~b}$. Table $3 \mathrm{a}$ shows all forms used in more than two percent of total contexts. The PF was the verb form used most frequently in future-time contexts $(35.5 \%)$, followed by the present forms (indicative, subjunctive, and forms that are ambiguous between the two), which together accounted for a full 31.9 percent. The third most frequent set of forms for the NSs is the IF and IFcond (18\%), whereas lexical futures (present, IF-cond, cond) together account for 12.6 percent. Finally, as shown in Table 3b, several forms are present in the data, albeit infrequently: lexical future conditionals and IF-conditionals, the futur antérieur, the futur antérieur (cond), conditional forms, and the PF in the subjunctive. For these minor forms (i.e., forms that are used in less in $2 \%$ of all future-time contexts), it is of note that eight of the ten NSs used at least one such form, suggesting that their use in future-time contexts is not due to the personal preference of a minority of speakers.

Table 3a. NS Distribution of Major Verb Forms used in Future-Time Contexts

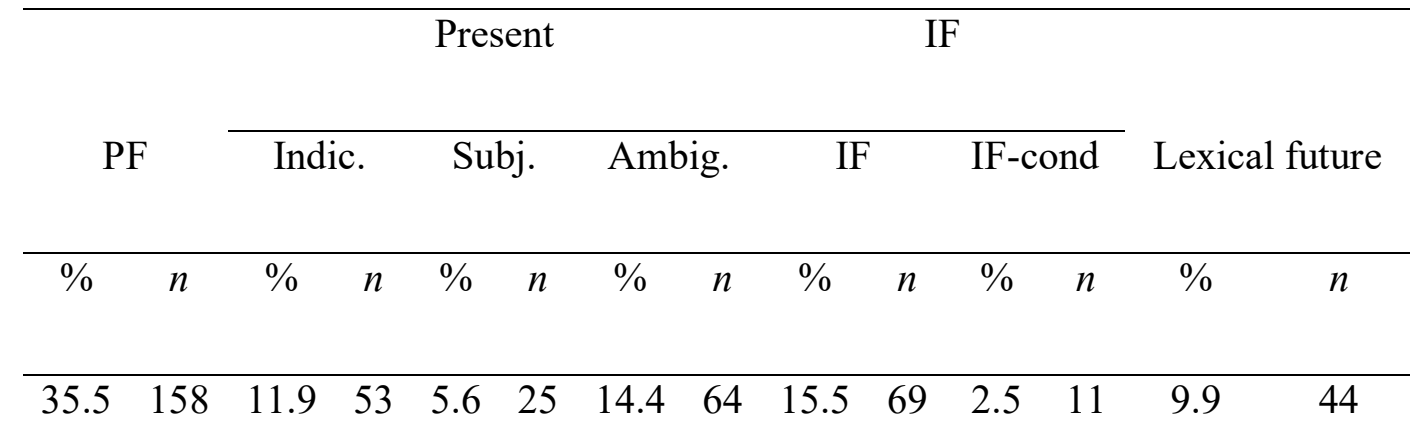

Table 3b. NS Distribution of Minor Verb Forms used in Future-Time Contexts 


\begin{tabular}{|c|c|c|c|c|c|c|c|c|c|c|c|}
\hline \multicolumn{4}{|c|}{ Lexical future } & \multicolumn{4}{|c|}{ Futur antérieur } & \multirow{2}{*}{\multicolumn{2}{|c|}{ Cond }} & \multirow{2}{*}{\multicolumn{2}{|c|}{ PF Subj }} \\
\hline \multicolumn{2}{|c|}{ Cond } & \multicolumn{2}{|c|}{ IF-Cond } & \multicolumn{2}{|c|}{ IF } & \multicolumn{2}{|c|}{ IF-Cond } & & & & \\
\hline$\%$ & $n$ & $\%$ & $n$ & $\%$ & $n$ & $\%$ & $n$ & $\%$ & $n$ & $\%$ & $n$ \\
\hline 0.9 & 4 & 1.8 & 8 & 0.5 & 2 & 0.2 & 1 & 0.7 & 3 & 0.7 & 3 \\
\hline
\end{tabular}

Presented in this fashion, our data are difficult to compare to previous research, insofar as most work on future-time expression in NS French has been limited to the IF and PF. To provide a point of comparison with the previous studies on native Hexagonal French, we reduced our NS dataset to only the occurrences of the IF and PF and converted the raw scores into percentages. For the sole purposes of comparability with previous studies, we have included all IF and IF-Cond tokens under "IF". The resultant dataset is small and represents only approximately half of all future-time contexts identified for our speakers ( $n=238$, as opposed to the full dataset of 445 occurrences). The newly calculated percentages are presented in Figure 1 as Donaldson, along with the data from Roberts (2012), Fleury and Branca-Rosoff (2010), Söll (1983), and Wales (1983). ${ }^{6}$ As can be seen in Figure 1, the PF (relative to the IF) is clearly dominant among our NSs, and slightly more so than has been reported in previous studies of Hexagonal French.

\footnotetext{
${ }^{6}$ Although Jeanjean (1988) reports that the IF is more frequent than the PF in the spoken French collected for the GARS corpus, in the analysis she presents, it is not clear whether the sample analyzed (57.8\% IF) is representative of the larger corpus.
} 


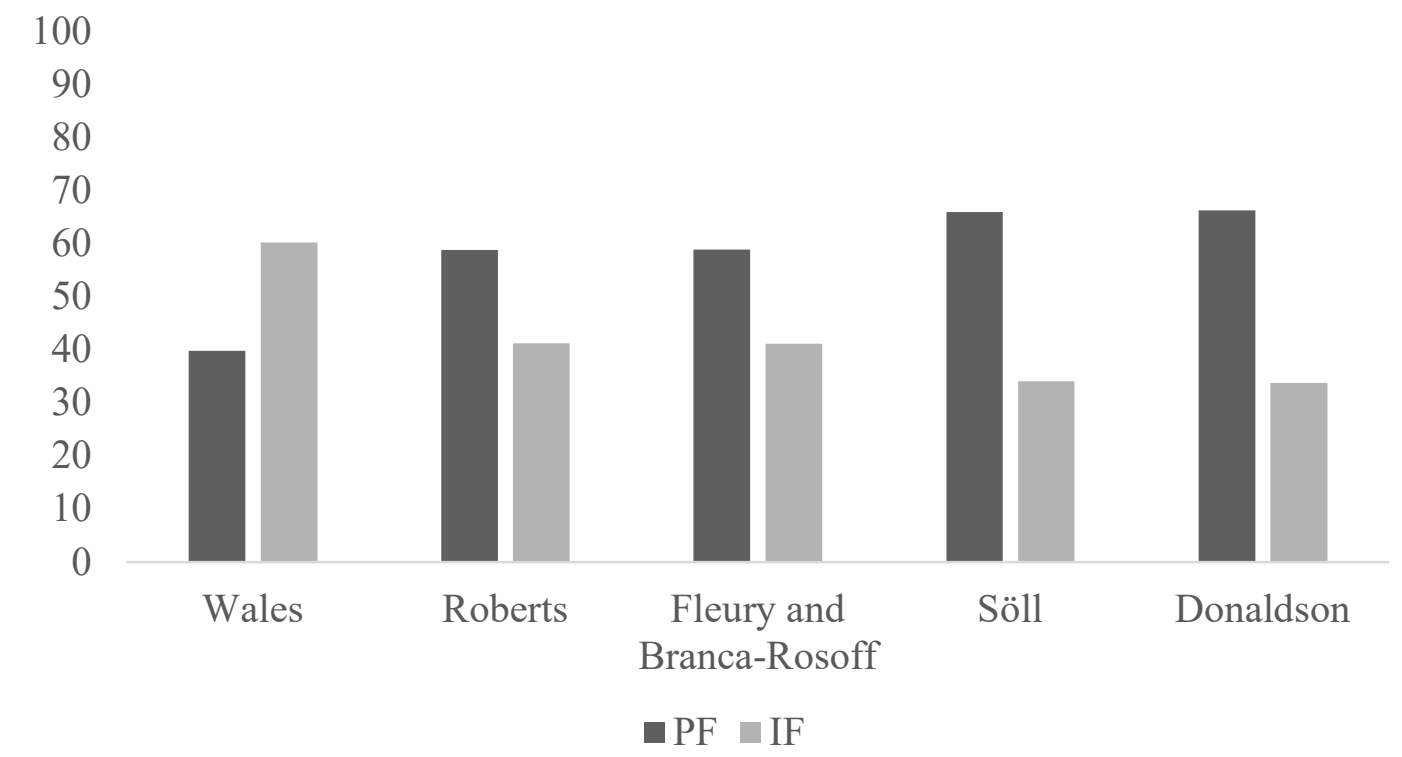

Figure 1. Comparison of PF versus IF in Native Hexagonal French (Oral Production).

NNS inventory and distribution. Turning now to our NNS data, we find that the ten speakers employed 11 verb forms and a total of 127 different lexical verbs in the 502 future-time contexts. The NNS data show exactly the same ranking as the NS data among the four most frequent verb forms (Table 4a), with the PF (39.6\%) being used most frequently, followed by the three present forms (29.1\%), the two IF forms $(15.7 \%)$, and finally the three lexical futures (14.3\%). As shown in Table $4 \mathrm{~b}$, the NNSs also used several minor forms in the expression of future time: lexical future conditionals and IFconditionals, futur antérieur (cond), and conditionals. A total of eight different NNSs used at least one of these four minor forms in the expression of future time. As opposed to the NSs, no instances of the PF subjunctive or futur antérieur were found for the NNSs.

Table 4a. NNS Distribution of Major Verb Forms used in Future-Time Contexts 


\begin{tabular}{|c|c|c|c|c|c|c|c|c|c|}
\hline \multirow{2}{*}{\multicolumn{2}{|c|}{$\mathrm{PF}$}} & \multicolumn{3}{|c|}{ Present } & \multicolumn{3}{|c|}{ IF } & \multirow{2}{*}{\multicolumn{2}{|c|}{ Lexical future }} \\
\hline & & Indic. & Subj. & Ambig. & IF & & IF-cond & & \\
\hline$\%$ & $n$ & $\%$ & $\%$ & $\%$ & $\%$ & $n$ & $\%$ & $\%$ & $n$ \\
\hline 39.6 & 199 & 12.261 & $4.4 \quad 22$ & $12.5 \quad 63$ & 10.4 & 52 & 5.2 & 12.7 & 64 \\
\hline
\end{tabular}

Table 4b. NNS Distribution of Minor Verb Forms used in Future-Time Contexts

Lexical future Futur antérieur

\begin{tabular}{cccccccccccc}
\hline Cond & IF-Cond & & IF & \multicolumn{2}{c}{ IF-Cond } & \multicolumn{2}{c}{ Cond } & \multicolumn{2}{c}{ PF Subj } \\
\hline$\%$ & $n$ & $\%$ & $n$ & $\%$ & $n$ & $\%$ & $n$ & $\%$ & $n$ & $\%$ & $n$ \\
\hline 1.2 & 6 & 0.4 & 2 & & - & 0.6 & 3 & 0.8 & 4 & & - \\
\hline
\end{tabular}

To situate our NNS data with respect to findings from previous L2 studies, we calculated percentages of use for the three forms reported on in previous research: PF, present indicative, ${ }^{7}$ and IF. In so doing, our NNS corpus shrinks from 502 to 379 futuretime contexts. These percentages are compared to the distribution of forms reported in four previous studies: Blondeau et al.'s (2014: 680) 29 Anglo-Montrealers, Nadasdi et al.'s (2003: 205) immersion students in Canada, the six most advanced students from Moses (2002: 138), and all 18 second- and third-year university participants reported on in Howard (2012: 213). As seen in Figure 2, the PF is dominant in the three studies where speakers are using French in a target-language environment: among Anglo-Montrealers,

\footnotetext{
${ }^{7}$ For purposes of comparison, this graph shows only present forms in indicative contexts $(n=102)$. Were we to include all present-tense forms $(n=146)$, the present would account for $34.4 \%$ of occurrences.
} 
immersion students, and our own NNSs. The two studies investigating learners in a university setting both find relatively high levels of IF in their oral interviews (although the number of total tokens for both Howard and Moses is relatively low, 104 and 116, respectively). Finally, the results from the present study stand out insofar as rates of futurate present use are only exceeded by findings from Howard (2012).

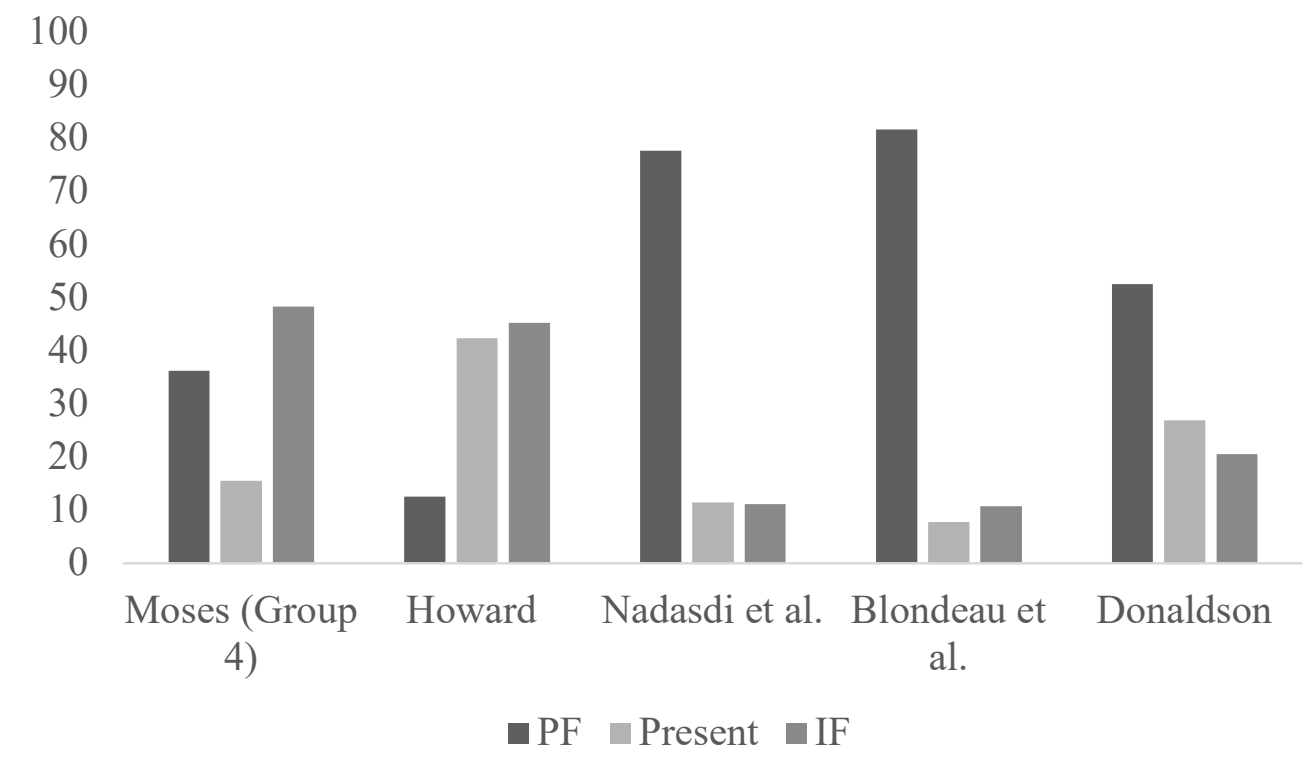

Figure 2. Comparison of Distribution of PF, Present, and IF in L2 French (Oral Production).

\section{Use of the Present to Make Reference to Future Time}

The futurate present has been identified as one of the three most frequent verb forms in future-time contexts in several studies of NS and L2 French. Interestingly, these forms account for a much larger portion of our data than reported in previous studies: Whereas Poplack and Turpin (1999) only found the futurate present in seven percent of their future-time contexts and Roberts (2012: 97) justified his decision to exclude the futurate present in his analysis of Hexagonal French in part because of 'the extremely low token numbers', these forms make up almost one third of our total corpus. We 
hypothesize that these strong differences in the percentage of present-for-future forms between our study and previous research may be due to two causes. First, given that our dataset of informal conversations is unique among studies of future-time expression, it is possible that the futurate present is more frequent in spontaneous, informal conversational data (as opposed to the speech elicited in sociolinguistic interviews reported in most previous studies). We leave this point to future research. Second, as already mentioned, most research has defined the futurate present as the co-occurrence of a presumably present indicative form and a future-time temporal adverbial (e.g., Blondeau, 2006: 74; Le Goffic and Lab, 2001: 78; Moses, 2002: 27). Although such instances are indeed counted among our set of present forms, they are not the majority. If we remove from our dataset all present-for-future forms with no temporal adverbial in the same clause as well as all forms that are clearly or presumably subjunctive, the futurate present would amount to only $13.2(n=46)$ and $10.3(n=41)$ percent of the NS and NNS corpora, respectively. Although these figures are more in line with previous research, there is no principled reason to restrict present-for-future in such a way within a conceptoriented analysis. One of the notable results of our approach is that it allows us to make the argument for a wider view of present-tense forms used in future-time contexts. We now take a closer look at two aspects of the present-for-future that have received little attention: its use with - but especially without - temporal adverbials and instances of the present subjunctive in future-time contexts.

Although generally claimed that a temporal adverbial is necessary for the present to be able to make reference to future time, it is unclear how "presence of a temporal adverbial" has been interpreted in previous research: Must the adverbial occur in the 
same clause, the same utterance, the same turn as the verb form? In our coding, we considered an adverbial to accompany a future-time context if it occurred in the same clause, and we indeed find that futurate present forms co-occur more frequently with temporal adverbials when compared to the overall corpus (Table 5). However, the cooccurrence between temporal adverbials and the futurate present is far from categorical, with only 40.8 percent of all NS present forms co-occurring with a lexical temporal indicator, a figure that drops to 32.2 percent in the NNS portion of the corpus.

Table 5. Future-Time Contexts that Co-Occur with a Temporal Adverbial.

\begin{tabular}{lcccc}
\hline & \multicolumn{2}{c}{ Overall corpus } & \multicolumn{2}{c}{ Futurate present } \\
\cline { 2 - 5 } Group & $\%$ & $n$ & $\%$ & $n$ \\
\hline NSs & $24.7 \%$ & $110 / 445$ & $40.8 \%$ & $58 / 142$ \\
NNSs & $21.5 \%$ & $108 / 502$ & $32.2 \%$ & $47 / 146$ \\
\hline
\end{tabular}

This result can be explained by the fact that temporal reference can be established by means other than an immediate temporal adverbial. It is possible - and, indeed, these are the most frequent examples in our corpus - for future temporal reference to be established elsewhere in the discourse, thus creating a future-time context in which the present can be used without the direct presence of an explicit lexical temporal indicator. Several such examples are provided in the exchange shown in (7). In this passage, the two speakers begin by discussing plans for the following Thursday, as established in NS7's first turn, before moving on to the topic of weekend plans, introduced by NNS7 in her third turn. 
(7) NS7 (331, 340): on va peut-être ressayer de le remporter jeudi après-midi parce qu'on les voit jeudi soir

NNS: ah d'accord

NS7 (318, 309, 339): et je pense qu'on pourra pas passer la journée avec nos bagages il faudra qu'on repasse par chez toi le soir

NNS7: ah d'accord

NS7 (299, 300, 301): tu me diras où on peut te laisser les clés ou si on claque la porte ou je sais pas

NNS7 (335): ouais si tu claques la porte bein moi je je ne sais pas encore pour euh mes projets de week-end tout est en train de changer mais euh

NS7: ah oui?

NNS7 (336, 337, 338): ouais parce que je suis fatiguée euh: les autres jours qui XX normalement je descends en Suisse avec un des copains [oui] mais les gens qui j'aime ne descendent pas forcément les gens qui je n'aime pas c'est pas je les aime pas mais c'est que je vais pas pouvoir supporter tu vois les chatches pendant quatre jours donc je ne sais pas

NS7: ça perd de son intérêt

NNS7 (339): oui c'est que en plus je pars en Suède le week-end après

NS7 (302): ah bon tu fais les deux parce que tu m'avais dit un moment Suisse ou Suède

In these eleven turns, we find no fewer than fourteen future-time contexts (see bolded verbs), of which eight are expressed using a futurate present. Of these eight, three occurrences are with an immediate temporal adverbial (on les voit jeudi soir, on repasse 
chez toi le soir and je pars en Suède le week-end après). In the remaining five instances, future temporal reference is established through other means. For the two examples involving the question of simply shutting the door, it is the immediately preceding mention by the NS of picking up of their luggage Thursday evening that allows the hearer to establish future reference. In the next turn, the NNS introduces the topic of her plans for the weekend. The establishment of future-time reference is made here not with a temporal adverbial per se, but with a noun phrase: mes projets de week-end. When the NNS speaks again, she is still on the topic of the coming weekend. Although she does not reiterate the future temporal reference, it is clear that her going to Switzerland is still referring to the weekend in question. Moreover, it should be pointed out that even if $j e$ descends en Suisse were the first introduction of the topic, the simple fact that the two people talking are in France - and are not on their way Switzerland - forces the hearer to choose between either a habitual reading (the speaker goes to Switzerland regularly) or a non-present (and, specifically, future) reading of the statement. At the end of this exchange, the NNS redefines the future temporal reference (to speak not about the coming weekend, but the weekend after), to which the NS responds using a futurate present non-accompanied by a temporal adverbial. We thus conclude that although the tendency to use the present to make reference to future time appears to increase in the presence of a temporal adverbial for both NSs and NNSs alike, one must bear in mind that in more than half of all uses of these forms, the present is in fact used in future-time contexts without the immediate presence of a lexical temporal indicator and that this is made possible because future-time reference in these cases has been established by other lexical or discursive-pragmatic means. 
The second point that our analysis allows us to address with respect to the futurate present concerns the use of the subjunctive in the expression of future time. We first note that these occurrences are less frequent, appearing in only 4.2 percent (NNSs) and in 5.4 percent (NSs) of future-time contexts. ${ }^{8}$ Although infrequent when compared to the other major forms, there is evidence that subjunctive use is actually four to five times higher in future-time contexts than in finite clauses more generally (see O'Connor DiVito, 1997: 51, who finds that only one percent of all finite clauses in spoken French contain an unambiguous subjunctive form). Several examples of subjunctive verb forms in futuretime contexts are provided in (8) and (9). In (8), the two speakers are discussing the fact that the NNS is going to pick up a friend at 7:45am the following Sunday.

NNS5 (225): pour aller à à à la Bastide de Chalos il faut que je parte d'ici à huit heures moins le quart alors?

NS5 (276): bah toi il vaut mieux que tu partes vendredi soir

NNS5: oh t'es pas gentil \{laughter\}

Whereas the two subjunctive forms in (8) are accompanied by a temporal adverbial, most subjunctives in future-time contexts, including (9a-b), are not. In (9a), the NS asks the NNS to be the godmother of her as yet unborn baby. She adds that if the baby is a girl, she would like the first name of the NNS to be part of the baby's name. These two states - being the godmother and the baby carrying the name of her godmother - cannot already be realized, given that the baby is not yet born. In the NNS example in (9b), the speaker

\footnotetext{
${ }^{8}$ Subjunctive forms in future-time contexts were introduced by a variety of triggers: il faut que, vouloir que, aimer que, pour que, le fait que, valoir que, avoir envie que, attendre que. The subordinate clause following these triggers was not systematically coded as a future-time context; this depended on discourse topic, shared knowledge, etc.
} 
is discussing her efforts to sell her house and then return to the United States. Context makes clear that the house is currently for sale and that the sale will happen in the future.

(9) a. mais si tu es d'accord on aimerait bien que tu sois la marraine du bébé \{ah\} alors deuxième question si c'est une fille j' voudrai(s) qu'il y ait [NNS's name] dans son nom si ça te dérange pas (NS7, 343, 344)

b. voilà. voilà: et euh (1s) et puis voilà donc j'ai envie qu'elle se vende vite pour pouvoir avancer (NNS1, 95)

The present subjunctive patterns in a clearly different manner from the other futurate present tokens with respect to temporal adverbials. Whereas NSs and NNSs tend to use both the present indicative and present ambiguous more frequently in the presence of a temporal adverbial, the present subjunctive is not favored by the presence of a lexical temporal indicator (compare Tables 5 and 6).

Table 6. Uses of Futurate Present that Co-Occur with a Temporal Adverbial.

\begin{tabular}{lcccccc}
\hline & \multicolumn{2}{c}{ Present indicative } & \multicolumn{2}{c}{ Present ambiguous } & \multicolumn{2}{c}{ Present subjunctive } \\
\cline { 2 - 6 } Group & $\%$ & $n$ & $\%$ & $n$ & $\%$ & $n$ \\
\hline NSs & $50 \%$ & $26 / 52$ & $40 \%$ & $26 / 65$ & $12.5 \%$ & $3 / 24$ \\
NNSs & $36.1 \%$ & $22 / 61$ & $36.5 \%$ & $23 / 63$ & $9.5 \%$ & $2 / 21$ \\
& & & & & & \\
\hline
\end{tabular}

Although we have no definitive explanation for this pattern, we note that both the subjunctive and the future forms (along with the conditional) are used in expressions in the irrealis domain, defined by Poplack (2001: 406) as 'the domain of imagined, projected, predicted or otherwise unreal situations or events.' In other words, it is perhaps no accident that a major exponent of subjunctive modality (i.e., the subjunctive present 
form) can also be used in future-time contexts without the support of a temporal adverbial (see also Bardovi-Harlig, in press, for mention of the future as a minor device for expressing the subjunctive mood and the subjunctive as a minor device for expressing futurity).

\section{Discussion}

The first part of this section is organized around our two research questions: Research question 1 examined the inventory of verb forms used by NSs and NNSs in the expression of future time, whereas research question 2 investigated the use of the present in expressing futurity. In the second part, we address the methodological and theoretical contributions of our analysis to the study of future-time reference in NS French and to the field of L2 acquisition more generally.

\section{Inventory of Verb Forms Used}

Research question 1 asked what verb forms are used to express the function of future-time reference by NSs and NNSs of Hexagonal French. Whereas most research into future-time expression in French has reported on the use of the PF and the IF (and the present, for certain studies), our investigation of all finite predicates whose realization was clearly set to occur after the moment of speaking revealed that the number of forms used in the expression of futurity is much larger than previously reported. As discussed in the Results section, this difference is at least in part due to the fact that certain coding decisions in previous research have likely been informed by prescriptive distinctions for those forms that are ambiguous in oral data (i.e., the IF and conditional forms in the firstperson singular and many present indicative and subjunctive forms). Finding these 
decisions questionable, we opted for the coding schema presented in (4), identifying 13 verb forms in the NS corpus and 11 in the NNS corpus. The NSs and NNSs were found to use a similar repertoire of forms, with only two minor forms - the futur antérieur and the PF subjunctive - being used by the NSs and not by the NNSs. Regarding the distribution of these forms (Tables $3 a$ and $3 b$ and Tables $4 a$ and $4 b$ ), the NS and NNS portions of our corpus are comparable, with PF and present forms dominating in both parts. Thus, in terms of their make-up, the NS and NNS portions of our corpus are largely similar.

\section{Present Forms in the Expression of Future Time}

Research question 2 examined how the present was used in making reference to future time in our corpus. In this way, our analysis provides a first empirical analysis of the use of present forms in future-time contexts by NSs and NNSs. Our analysis of the present-for-future confirmed that both the present indicative and the present ambiguous are more frequent in the presence of a temporal adverbial, although the lack of such a temporal marker by no means results in the complete avoidance of such forms. As for the present subjunctive, the distribution of this form does not appear to be connected to the presence of a lexical temporal indicator, a fact that may be linked to its use in the expression of irrealis. What comes out of our analysis is that future-time reference can be signaled in many different ways, and that present forms - which are highly multifunctional - can be used in future-time contexts when such time reference has been established by temporal adverbials, but also when the temporal frame has been established elsewhere in the discourse. Although this sample of NNSs uses the presentfor-future in similar ways as the NSs, previous research by Edmonds and Gudmestad (2015) using a written selection task found that the greatest differences between the NSs 
and four L2 groups concerned the selection of the present for future-time expression. It was concluded that appropriate selection of the present-for-future is acquired late in L2 French; the current study suggests that such acquisition may indeed be possible at very high levels of proficiency.

A final point to be made concerning the use of present forms in the expression of future time is related to the potential role of lexical aspect. In our discussion of the present-for-future, we alluded to the fact that certain predicates (in particular, telic ones) in the present may in fact tend towards a future reading (see our previous discussion of the example je descends en Suisse). Although we did not examine lexical aspect in the current project, much previous research has already established the importance of the relationship between lexical aspect and past-time expression (see Andersen and Shirai, 1996). This factor has also received some attention with respect to future-time reference (see Helland, 1995, for French, Kanwit, 2014, for Spanish, Wiberg, 2002, for Italian) and may merit investigation in future research.

\section{Overarching Contributions}

The present findings contribute to research on future-time expression in French at both the methodological and theoretical levels. In terms of method, we highlighted the fact that what is meant by $I F$ and present varies from one researcher to another. Moreover, most linguists have not specified how they coded for the presence of temporal adverbials. In our study, we have attempted, as far as possible, to illustrate and to justify our own coding choices, arguing that such transparency is essential to refining research within this area. In addition, we hope to have made a convincing argument for the interest of concept-oriented analyses for different aspects of language systems and for different 
participant populations. This type of analysis constitutes an interesting and perhaps necessary complement to other functional approaches. Within variationism, for example, the Principle of Accountability (Labov, 1966: 49) requires that the analyst examine all relevant forms in the system of grammar under study. 'The idea is that the analyst cannot gain access to how a variant functions in the grammar without considering it in the context of the subsystem of which it is a part. Then each use of the variant under investigation can be reported as a proportion of the total number of relevant constructions, i.e., the total number of times the function (i.e., the same meaning) occurred in the data.' (Tagliamonte, 2012: 10) What is described here by Tagliamonte is precisely what a concept-oriented analysis aims to do. As we have pointed out throughout this paper, making reference to future time in French involves much more than the PF and IF. Studies that limit their scope to these forms are unable to truly gain access to how a variant functions in a given subsystem of the grammar (see Aaron, 2010).

Moving now to future-time expression in NS French, we note that this study has contributed to the description of French as it is spoken in France. However, much work remains to be done on Hexagonal French. First and foremost, the corpus analyzed in this study is not sufficiently large in order to be representative of Hexagonal French. It thus remains for future research to determine whether the patterns observed in the present data generalize across a larger dataset that includes a wider range of registers and communicative contexts. In addition, although our sampling procedure was based around a set of NNSs located mostly in the Southwest of France, their self-selected NS interlocutors were not all from this region. At this stage, it is thus impossible to know if future-time reference looks different in different parts of France. The important 
differences in the expression of futurity from one Canadian French variety to another lead us to suggest that future projects should carefully control for this variable. Nonetheless, we feel that the picture painted in this study allows us to establish a more detailed NS baseline for Hexagonal future-time reference, a benchmark that is particularly important when working within the field of L2 acquisition, as it allows us to make comparisons between L2 speakers at various levels of proficiency and NS use.

This brings us to the contributions made by this study to the field of L2 acquisition, and most notably to the discussion on near-native attainment. Previous research into NNSs of French has demonstrated that they closely approximate NS norms with respect to a variety of characteristics, including the use of formulaic language (Bartning, Forsberg, and Hancock, 2009), clefts and focus (Donaldson, 2012), interrogatives (Donaldson, 2016), among others. However, it has also been demonstrated that NNSs continue to differ from NSs in their use of morphosyntactic structures (see Bartning, Forsberg Lundell, and Hancock, 2012). To the best of our knowledge, studies examining how such high achieving L2 users (of any language) fare with variable structures (such as future-time expression) are rare (but see Blondeau et al., 2014). Such structures present particular learning challenges, insofar as one must both learn what different forms can be used to express a given meaning, but also how to decide amongst the different possibilities for any given expression of that meaning. In our view, adopting a concept-oriented perspective to investigate the use of variable structures by NNSs is particularly relevant, insofar as such a rich and broad perspective allows us to examine how such speakers use both the most frequent ways of expressing a certain meaning, but also those means that are rarer. In our investigation of the expression of future-time, our 
concept-oriented approach allowed us to reveal remarkable similarities in the two portions of our corpus for the expression of a variable structure: NSs and NNSs make use of almost exactly the same set of verbal forms and these forms show similar distributions in the two speaker groups.

We interpret this close approximation as a successful application of what Andersen (1990) termed the multifunctionality principle. According to Andersen (1984, 1990), early L2 acquisition in particular is characterized by the one-to-one principle, namely the mapping of one form to one meaning, a tendency that he hypothesizes is due to processing constraints. For future-time expression, this may take the form of one verb form dominating in the expression of future time, which is precisely what was reported by Bardovi-Harlig (2004) for L2 English (will was the dominant form in early interlanguage). However, Andersen goes on to write that 'when a learner moves away from a one-to-one representation of form to meaning it is usually in the direction of multifunctionality in existing forms (along with addition of new forms)' (1990: 53). The present results represent the other end of the L2 developmental spectrum, and demonstrate that these NNSs appear to have been successful in developing multiple functions (or meanings) for a form (e.g., with present forms), and multiple forms for the single meaning of future-time reference.

\section{Conclusion}

Our concept-oriented approach to variable future-time expression among NSs and NNSs of Hexagonal French has provided a broad account of verbal means used in the expression of futurity, contributing to research on future-time expression in NS French 
and to investigations into near-nativeness in L2 acquisition. In particular, we found that NSs of Hexagonal French drew on an inventory of 13 different verb forms in future-time contexts, and NNSs used 11 different verb forms and that in both portions of our corpus, $\mathrm{PF}$ and present-for-future forms accounted for more than 60 percent of all occurrences, whereas the IF accounted for only between 15.6 and 18 percent. Finally, our analysis of the present-for-future highlighted its use in contexts in which future-time reference had been established via means other than adverbials. Whereas most research into the expression of temporality has focused on the past, our findings demonstrate the complexity involved in the expression of the future in NS and NNS French. Among other things, future-time reference implicates the larger discourse context, the mood system (e.g., the use of lexical futures and the subjunctive in future-time contexts), and potentially lexical aspect. Concept-oriented approaches, with their broad and multi-level (i.e., lexical, morphological, discursive, pragmatic, etc.) view of the expression of a given concept, are an important tool to arriving at a better understanding of how speakers make reference to future time. They also show great potential to help researchers respond to Bardovi-Harlig's (in press) call to move research from individual form-meaning pairings to a better understanding of the tense-aspect-mood system more generally. 


\section{References}

Aaron, J. E. (2010). Pushing the envelope: Looking beyond the variable context. Language Variation and Change, 22: 1-36.

Andersen, R. W. (1984). The one-to-one principle of interlanguage construction. Language Learning, 34: 77-95.

Andersen, R. W. (1990). Models, processes, principles and strategies: Second language acquisition inside and outside the classroom. In: B. VanPatten and J. F. Lee (eds), Second Language Acquisition-Foreign Language Learning. Clevedon, UK: Multilingual Matters, pp. 45-78.

Andersen, R. W., and Shirai, Y. (1996). The primacy of aspect in first and second language acquisition: The pidgin-creole connection. In: W. C. Ritchie and T. K. Bhatia (eds), Handbook of Second Language Acquisition. San Diego, CA: Academic Press, pp. 527-270.

Bardovi-Harlig, K. (2004). The emergency of grammaticalized future expression in longitudinal production data. In: M. Overstreet, S. Rott, B. VanPatten, and J. Williams (eds), Form and Meaning in Second Language Acquisition. Mahwah, NJ: Erlbaum, pp. 115-137.

Bardovi-Harlig, K. (2005). The future of desire: Lexical futures and modality in L2 English future expression. In: L. Dekydtspotter, R. A. Sprouse, and A. Liljestrand (eds), Proceedings of the $7^{\text {th }}$ Generative Approaches to Second Language Acquisition Conference. Somerville, MA: Cascadilla Proceedings Project, pp. 112. 
Bardovi-Harlig, K. (2007). On functional approach to second language acquisition: The concept-oriented approach. In: B. VanPatten and J. Williams (eds), Theories in Second Language Acquisition: An Introduction. London: Routledge, pp. 57-75.

Bardovi-Harlig, K. (in press). Beyond individual form-meaning associations in L2 tensemood-aspect research. In: M. Howard and P. Leclercq (eds), Tense-Mood-1spect in Second Language Acquisition. Amsterdam: Benjamins.

Bartning, I., Forsberg, F., and Hancock V. (2009). Resources and obstacles in very advanced L2 French: Formulaic language, information structure and morphosyntax. EUROSLA Yearbook, 9: 185-2011.

Bartning, I., Forsberg Lundell, F., and Hancock V. (2012). On the role of linguistic contextual factors for morphosyntactic stabilization in high-level L2 French. Studies in Second Language Acquisition, 34: 243-267.

Birdsong, D. (1992). Ultimate attainment in second language acquisition. Language, 68: 706-755.

Blondeau, H. (2006). La trajectoire de l'emploi du futur chez une cohorte de Montréalais francophones entre 1971 et 1995. Revue canadienne des langues vivantes, 9: $73-$ 98.

Blondeau, H., Dion, N. and Ziliak Michel, Z. (2014). Future temporal reference in the bilingual repertoire of Anglo-Montrealers: A twin variable. International Journal of Bilingualism, 18(6), 674-692.

Bybee, J. L., Perkins, R. and Pagliuca, W. (1994). The evolution of grammar: Tense, aspect, and modality in the languages of the world. Chicago: University of Chicago Press. 
Comeau, P. (2011). A window on the past, a move toward the future: sociolinguistic and formal perspectives on variation in Acadian French. Unpublished doctoral dissertation, York University.

de Saussure, L. (2013). Perspectival interpretations of tenses. In K. Jaszczolt \& L. de Saussure (Eds.), Time: Language, cognition \& reality (pp. 45-72). Oxford: Oxford University Press.

Deshaies, D. and Laforge, E. (1981). Le futur simple et le futur proche dans le français parlé dans la ville de Québec. Langues et linguistique, 7: 21-39.

Donaldson, B. (2011). Left dislocation in near-native French. Studies in Second Language Acquisition, 33: 399-432.

Donaldson, B. (2012). Syntax and discourse in near-native French: Clefts and focus. Language Learning, 62: 902-930.

Donaldson, B. (2016). Aspects of interrogative use in near-native French: Form, function, and register. Linguistic Approaches to Bilingualism, 6(4): 467-503.

Donaldson, B. (in press). Negation in near-native French: Variation and sociolinguistic competence. Language Learning.

Edmonds, A. and Gudmestad, A. (2015). What the present can tell us about the future: A variationist analysis of future-time expression in native and nonnative French. Language, Interaction, Acquisition, 6(1): 15-41.

Ellis, R. (2008). The study of second language acquisition (2 ${ }^{\text {nd }}$ ed.). Oxford: Oxford University Press. 
Emirkanian, L., and Sankoff, D. (1985). Le futur simple et le futur périphrastique. In: M. Lemieux and H. J. Cedergren (eds), Les tendances dynamiques du français parlé à Montréal (tome 1). Gouvernement du Québec, pp. 189-204.

Fleury, S. and Branca-Rosoff, S. (2010). Une expérience de collaboration entre linguiste et spécialiste de TAL: l'exploitation du corpus CFPP 2000 en vue d'un travail sur l'alternance future simple / future périphrastique. $A F L S, 16(1), 63-98$.

Grimm, D. R. (2010). A real-time study of future temporal reference in spoken Ontarian French. University of Pennsylvania Working Papers in Linguistics, 16(2): 83-92.

Grimm, D. R. (2015). Grammatical variation and change in spoken Ontario French: The subjunctive mood and the expression of future temporal reference. Unpublished doctoral dissertation, York University.

Grimm, D. R. and Nadasdi, T. (2011). The future of Ontario French. Journal of French language studies, 21: 173-189.

Gudmestad, A. and Edmonds, A. (2015). Categorical and variable mood distinction in Hexagonal French: Factors characterizing use for native and non-native speakers. Canadian Journal of Applied Linguistics, 18(1) : 107-130.

Gueunier, N., Genouvrier, E. and Khomsi, A. (1978). Les Français devant la norme: Contribution à une étude de la norme du français parlé. Paris: Champion.

Hansen, B. A. and Strudsholm, E. (2006). Morphological and periphrastic future in French and Italian spoken language: Parallel tendencies? La linguistique au cœur : valence verbale, grammaticalisaiton et corpus. Mélanges offerts à Lene Schøsler à l'occasion de son $60^{e}$ anniversaire (pp. 189-218). Odense: University Press of Southern Denmark. 
Helland, H. P. (1995). Futur simple et futur périphrastique : du sens aux emplois. Revue Romane, 30(1), 3-26.

Howard, M. (2012). From tense and aspect to modality: The acquisition of future, conditional and subjunctive morphology in L2 French. A preliminary study. Cahiers Chronos, 24 : 201-223.

Jeanjean, C. (1988). Le futur simple et le futur périphrastique en français parlé: étude distributionnelle. In: C. Blanche-Benveniste, A. Chervel and M. Gross (eds), Grammaire et Histoire de la Grammaire: Hommage à la Mémoire de Jean Stéfanini. Paris: Publications de l'Université de Provence, pp. 235-257.

Kanwit, M. (2014). The acquisition of future expression in L2 Spanish. Unpublished doctoral dissertation, Indiana University.

King, R. and Nadasdi, T. (2003). Back to the future in Acadian French. Journal of French language studies, 13: 323-337.

Labov, W. (1966). The social stratification of English in New York City. Washington, D.C.: Center for Applied Linguistics.

Le Goffic, P. and Lab, F. (2001). Le présent « pro futuro ». Cahiers Chronos, 7: 77-98.

Moses, J. G. (2002). The development of future expression in English-speaking learners of French. Unpublished doctoral dissertation, Indiana University.

Nadasdi, T., Mougeon, R. and Rehner, K. (2003). Emploi du 'futur' dans le français parlé des élèves d'immersion française. Journal of French language studies, 13: 195219. 
O'Connor DiVito, N. (1997). Patterns across spoken and written French: Empirical research on the interaction among forms, functions and genres. Boston: Houghton Mifflin.

Poplack, S. (2001). Variability, frequency, and productivity in the irrealis of French. In: J. Bybee and P. Hopper (eds), Frequency and the Emergence of Linguistic Structure. Amsterdam: Benjamins, pp. 405-428.

Poplack, S. and Dion, N. (2009). Prescription vs. praxis: The evolution of future temporal reference in French. Language, 85: 557-587.

Poplack, S., Lealess, A. and Dion, N. (2013). The evolving grammar of the French subjunctive. Probus, 25: 139-195.

Poplack, S. and Turpin, D. (1999). Does the futur have a future in (Canadian) French? Probus, 11: 133-164.

Roberts, N. S. (2012). Future temporal reference in Hexagonal French. University of Pennsylvania Working papers in linguistics 18: 97-106.

Söll, L. (1983). De la concurrence du futur simple et du futur proche en français modern. In: F.-J. Hausmann (ed), Etudes de Grammaire Française Descriptive. Heidelberg: Julius Groos Verlag, pp. 16-24.

Tagliamonte, S. A. (2011). Variationist sociolinguistics: Change, observation, interpretation. New York: Wiley-Blackwell.

von Stutterheim, C. and Klein, W. (1987). A concept-oriented approach to second language studies. In: C. W. Pfaff (ed), First and Second Language Acquisition Processes. Cambridge, MA: Newbury House, pp. 191-205.

Wales, M. (1983). The semantic distribution of aller + infinitive and the future tense in spoken French. General Linguistics, 23, 19-28 
Wiberg, E. (2002). Information structure in dialogic future plans: A study of Italian native speakers and Swedish preadvanced and advanced learners of Italian. In: R. Salaberry and Y. Shirai (eds), Tense-Aspect Morphology in L2 Acquisition. Amsterdam: Benjamins, pp. 285-321. 